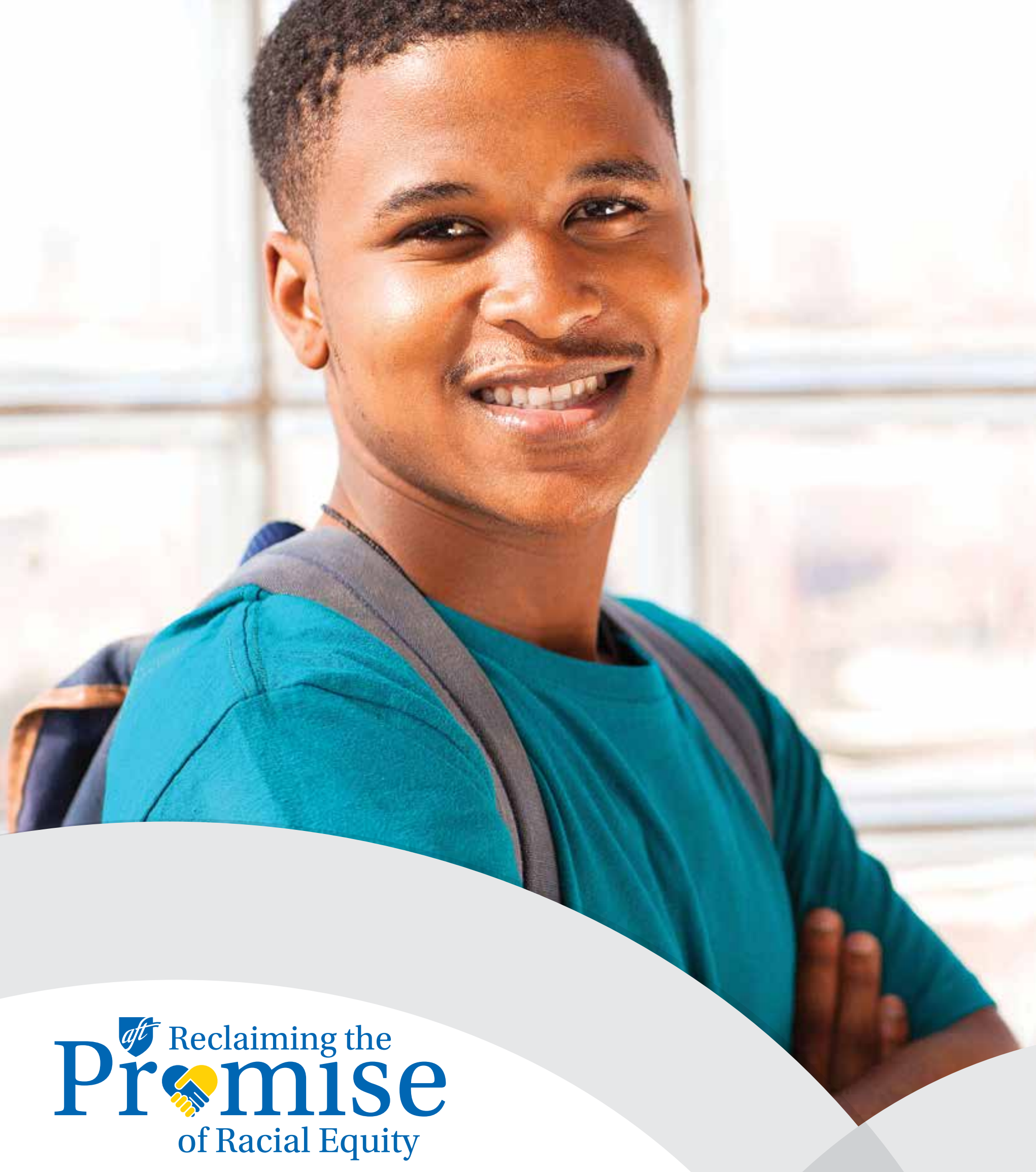

Reclaiming the Promise of Racial Equity in Education, Economics and Our Criminal Justice System

A REPORT OF THE AMERICAN FEDERATION OF TEACHERS RACIAL EQUITY TASK FORCE 


\section{From The Officers}

"I have been humbled and heartened by the overwhelming response from leaders and members around the country who participated in our union's courageous conversations. So many of our leaders and members called or emailed me directly to express gratitude and pride in our union taking on this important issue, and so many stepped up to be a part of this work. This work will take the efforts of all of our members, and especially support and participation by our white sisters and brothers. I am proud that the AFT is the first union in the labor movement to address this crisis of black males in a significant way."

LORRETTA JOHNSON, AFT secretary-treasurer and Racial Equity Task Force char

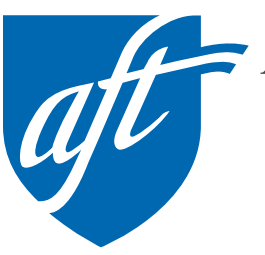

Union of Professionals

Randi Weingarten

PRESIDENT

Lorretta Johnson

CRETARY-TREASUREF

Mary Cathryn Ricker

PRESIDEN

\section{OUR MISSION}

The American Federa opportunity; and high-quality public education, healthcare and public services for our students, their families and our communities. We are committed to advancing these principles through community engagement, organizing

Copyright $₫$ American Federation of Teachers, AFL-CIO (AFT 2015). Permission is hereby granted to AFT state and local affiliates to reproduce and distribute copies of the work for nonprofit education purposes, provided that copies are distributed at or below cost, and that the author, source, and copyright notice are included on each copy. Any
AS THE AFT CELEBRATES its first 100 years, we honor our proud history as a union that has sounded the alarm and led the fight for economic, social and racial justice. In 1918, just two years after our union was founded, the AFT fought for equal pay for African-American teachers, for the election of African-Americans to local school boards, and for compulsory school attendance for African-American children. The AFT was the only education organization to file an amicus brief in support of the plaintiffs in the landme amicus Board of Education case in which the US. Supreme Cout Bolish Education case in which the U.S Suprene Count first trade unions to ex sho full me also were among the first trade unions to extend full menbership to people of This was a just, but un sepregated afliates to integrate. This was a just, but un

As our union enters its second century, our fight for a America that lives up to its promise of liberty and justice for all is not yet won. Separate but equal is no longer the law of he land, but systemic inequity in education has relegate millions of children of color to under-resourced, struggling schools. Black households have less than one-tenth the wealth of white households, on average, an outrageous reality that continues to get worse. Not since Reconstruction have there been as many attempts to restrict the right to vote. There has been an alarming number of incidents of police-involved violence against black men, women an children. The tragic deaths of Michael Brown in Ferguson, Mo., Eric Garner in New York City, Tamir Rice in Cleveland, Walter Scott in North Charleston, S.C. Sandra Bland in Waller County, Texas, and several other unarmed blacks who have died during or following encounters with the police underscore a broader crisis rooted in centuries of racia inequality in our nation.

Last October, members of the AFT executive council had blunt, tough, uncomfortable, but important conversatio to determine how our union could address the lingering effects of racism and inequality and, in particular, the impact on black males. As a result of that groundbreaking discussion, the council approved a statement of intent, "Closing the Achienent Gap for Black Mass" that detils how black men and boys are persistently denied equal access to educational and conomic opportunity Laying the groundwork for our fight forwar for justice, the statement also established the AFT's Racial Equity Task Force.

The primary goal of the task force has been to help determine what role the AFT can play in the fight for racial equity. The task force afso can play in the fight for racial eqentire task force also has examined ways to engage our a conversation on how the AFT can work for transformative changes in on how the AFT can work for transformative communities and our nation.

The executive council named AFT secretary-Ireasurer Lorretta Johnson to chair the task force. Johnson decided to cast a broad net and open membership to anyone-regardless of rank or position-who wanted to serve.

In January 2015, the AFT launched a series of conversations with leaders and members around the nation on racialin- 


\section{AFT Racial Equity Task Force}

equality. Those discussions-at each of the AFT's program and policy council meetings, at constituency and committee meetings, and at affiliate conferences- were blunt and passionate, and yielded a diverse group of volunteers to serve on the newly formed task force.

The executive council determined that the work of the task force should focus on developing real, union-driven solutions to address racial justice, particularly what has happened to black males. The decision to narrow the scope of the task force's work, however, is in no way meant to marginalize or minimize the challenges and struggles of other oppressed groups. Our work in racial equity will strengthall working Americans, including women, people of color, the disabled, ethnic minorities, immigrants and members of the LGBT community. We are confident the AFT's effors

In unity,

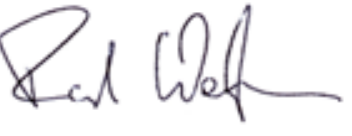

Randi Weingarten

PRESIDENT to fight inequities for black males will help reclaim our nation's promises of liberty and justice for all people.

Today, a grass-roots movement-fueled by the growing crisis around racial inequities in our nation-has emerged. A new generation is standing and delivering a fervent demand for racial justice. We must recognize that their fight is our fight and their struggle is our struggle. This movement shows us that it is not enough to be against discrimination. We must act to fundamentally change a society in which black lives have been demeaned. Now is the time to seize this unique moment to reaffirm our union's commitment to this fight forward.

We sincerely thank the members of the Racial Equity Task We ser the contribution of their time, to this important work.

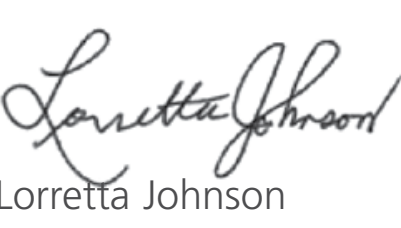
Lorretta Johnson SECRETARY-TREASURER

\section{Manz Cathron Rick Mary Cathryn Ricker} EXECUTVE VICE PRESIDENT
The Racial Equity Task Force has

now met twice, both times in cities Baltimore and St. Louis-that have become important battlegrounds in the fight for racial justice. Over the past year, racial tensions erupted in community uprisings and international attention following tragic events in both metropolitan areas, underscoring the urgency of the work of the task force.

The inaugural task force meeting took place in June 2015 in Baltimore, just two months after Freddie Gray just unarmed black man-died from inJuries he sustaind in police cos in -

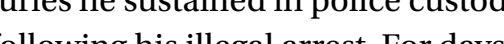
crov's after Gray's death, he protostors ome peaceful and sone not-took

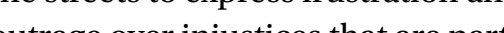
outrage over injustices that are part of everyday life for too many. In May, Baltimore State's Attorney Marilyn Mosby filed charges against six city police officers after a medical examner ruled Gray's death a homicide. Those officers all will face trial later his year and early next year. Mosby was one of several Baltimore officials who attended the meeting to welcome task force members to the city.

In August 2015, the task force met in St. Louis, a short distance from Ferguson, Mo.-the small suburban community where Michael Brown died a year earlier in a police-involved shooting. A week before the task force meeting local elected fficials declared a state of em in Ferguson when protests markeng hereng in . eace had been restored by he ting Louis for the meeting.
At both meetings, task force member were divided into smaller working groups to delve into the three major issue areas that were identified as a result of the union-wide conversations around racial inequalities. The three groups were the:

- Educational Justice Working Group, - Economic Justice Working Group, an - Criminal Justice Working Group.

The greater part of the task force's time was spent developing recommendations during working group sessions. In addition, experts in education, economics and the criminal justice system addressed participants during plenary sessions to help

provide a framework for the working group sessions.

The members of the Racial Equity Task Force have developed a frame for our union's work-at the national, state and local levels. Rather than culmination of this task force, this report marks the beginning of an ongoing, multifaceted effort that must be integrated into the work, goals, advocacy and mission of our union.
This report of the Racial Equity Task Force expresses our shared vision and charts a path for our union in the fight to reclaim the promise of racial equity. 
The American Federation of Teachers That's the only way we can ensure is a union that strives to give voice to effective teaching and learnin the professional, economic and social Zero-tolerance policies were an aspirations of our members and their attempt to make schools and classfamilies. We recognize that these aspirations for a better quality of life-at nize zero-tolerance has not worked. work, in our communities and in our We need policies that will help ensure nation-form the basis of a shared that our schools truly do provide safe vision that unites us all. But for more and welcoming spaces for students than a century, race, the racial divide and educators. That is a major area and inequity based on race have been for discussion that has been adused to try to divide American work- dressed in this report, and that will ers and prevent them from joining $\quad$ require that we continue to have contogether around the aspirations that together

The fight for racial equity cannot be separated from the fight for economic justice, and equal access to public education is a building block to lic education is a building block to economic parity. And the right to vo
is the right to have a say in our lives, is the right to have a say in our lives, our communities and our countr. They are all interwoven. For too many black men and boys, howeve the path to economic opportunity through education is obstructed and cut off by inequities that exist and persist in our criminal justice syste We aspire to live in communities and in a nation where the promise of racial equity becomes a reality for all. We seek to unite students, parents, teachers, and faith and community allies to reject efforts to deprive our public schools of resources; to fight back against those who blame teachers, unions and parents for school "failure"; and to resist efforts to close and privatize our public schools and privarize our public schools, trugeling stros hat serve communities of color. We also recognize the need to address the impact of disparities that exist in the enforcement of student discipline policies. Our schools absolutely have to be safe, welcoming and caring spaces for students and educators.
We envision an economic system that provides black men access to and opportunity for jobs with good wages, security and dignity by:

Ensuring equitable access to a high-quality education from early childhood through postsecondary -including career and technica education - that opens the door pendence.

Engaging with all workers and fighting for a "living wage" for every job. - Working for more just tax policies by ensuring that the wealthy pay their fair share and strengthening the safety net for those who need it. - Investing in affordable home

ownership opportunities and elimownership opportunities and eliminating predatory lending practices to create strong communities where all families a build wealth.

We envision an equitable crimina justice and judicial system that ensures fair treatment of black men an boys by:

- Developing truly rehabilitative alternatives to incarceration, such as prosrams, and making these the solution of first resort in the judicial solution of
system.

- Encouraging community policing - Encouraging community policing
and cultural competency training for police departments.

Opposing private and for-profit jails and prisons.

- Working to address contributing socioeconomic factors-like inceasing the high school - lide intion comployment
For too long, America has broken its promise of liberty and justice for all. The doors of educational and economic opportunity remain firm closed for many men and boys of color. Systemic cultural and institutional racism-rooted in a legacy that extends back more than 400 yearshas created and perpetuated a state crisis for black males in America.

Black male students lag far behind their white counterparts in several measures of educational attainment. Geasures of eates for black males Graduation heewest ang all students, which cos 38 states and the District each. of Colunbia, black lowest graduation rates. While the natonal graduation rate for black males has increased by 10 percent since 2001 , there continues to be a staggering gap between graduation rates for black male students (52 percent) white male students (78 percent) [Figure 1]

Black male achievement in math reading and science falls significantly below that of whites. In 2013, fourthgrade black male students scored an average of 27 points lower in math and 29 points lower in reading than their white counterparts. That same year, eighth-grade black males scored an average of 33 points lower in math and 26 points lower in reading than white male students.

Starting as early as preschool, black male students are affected, disproportionately, by suspensions, expulsions and zero-tolerance discipline policies in schools. Black male students are far more likely to be suspended or expelled from school, which causes them to lose access to valuable classroom instruction and significantly increases the likelihood of contact with law enforcement and the criminal justice system.

Data from the 2011-12 academic yea show that black children-both boys and girls-represented just 18 percen of preschool enrollment but accounted for 42 percent of the number of preschool children suspended once and 48 percent of those suspended more than once. Also in 2011-12, 20 percent of black boys received out-ofschool suspensions, compared with just 6 suspensions, compared with that same period 26 bercent of expulsions were black male students. [Figure 2]

Black students-boys and girlsare more likely to have their school discipline issues referred to local law enforcement. In 2011-12, black students represented 16 percent of total student enrollment, but 27 percen were referred to law enforcement and 31 percent were subjected to school-related arrest.
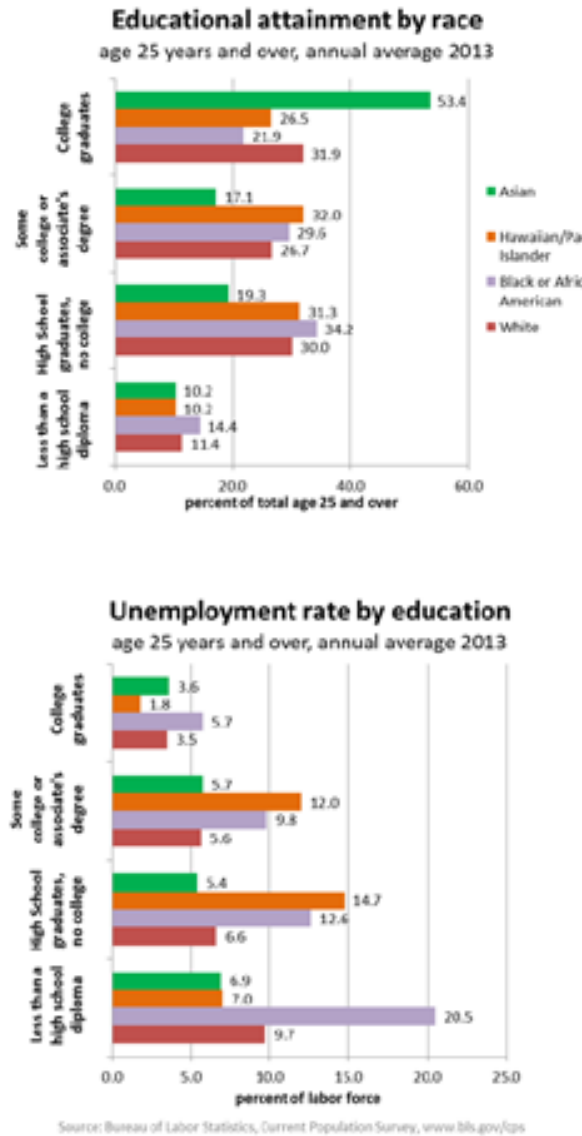

Students Receiving Out-of-School Suspensions

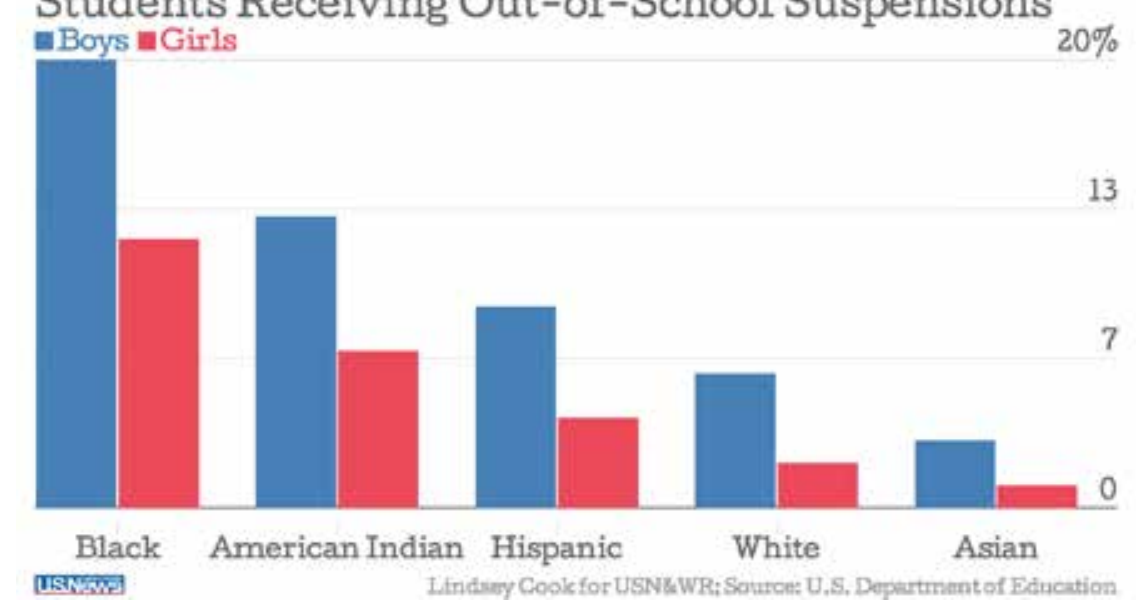


Figure 3

Unemployment rate, by age and race

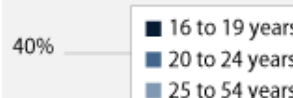

$30 \%$

$20 \%$

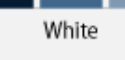

Hispanic

Figure 4

Men Women

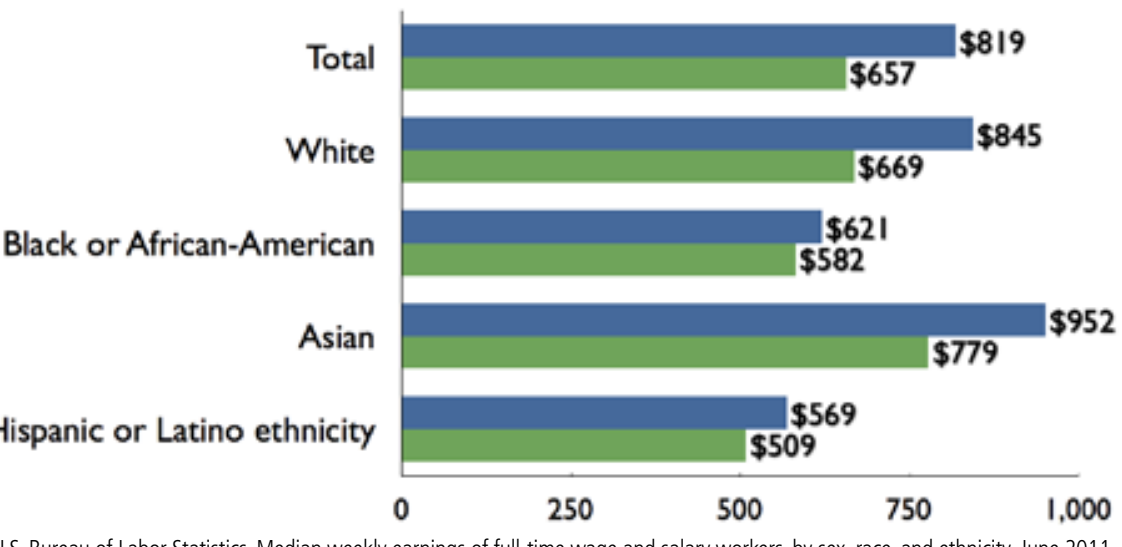

$\begin{array}{lllll} & \text { U.S. Bureau of L Labor Statisticis. Median weekly earnings of full-time wage and salary workers by sex } & 750 & 1,000\end{array}$
The decline in the share of the teaching workforce represented by blac also presents a significant obstacle to equality and opportunity for African-American students. A recent study of nine cities by the Albert Shanker Institute found a sharp decline in the number of black teachers. The AFT believes all students benefit from a diverse teaching force.

Studies show that a college degree is a major factor in earning potential, but black males make up less than

5 percent of America's college students. What's more, their graduation res are roughly half that of blation wome wonto atend college of his more than their white counterparts. the larger debt is conpon blacks and whites.

Black male employment and income levels continue to lag behind the

levels for white males. Deindustrial-

ization has hurt both black and white

workers, but it has disproportionately harmed black workers. While the

white male unemployment rate is 4.9 percent, the rate for black males is 10.8 percent, according to recent data from the Department of Labor

[Figure 3]

Black men also are disproportionately consigned to low-wage occupations, with nearly half of the black male workforce ( 46 percent) employed in the lowest-earning occup loyed in the lowest an accupation fields. on pecent of what whe median income for black male-headed households is $\$ 43,009$, compared by white males. [Figure 4 ]
Child poverty nationwide, by race, 2005

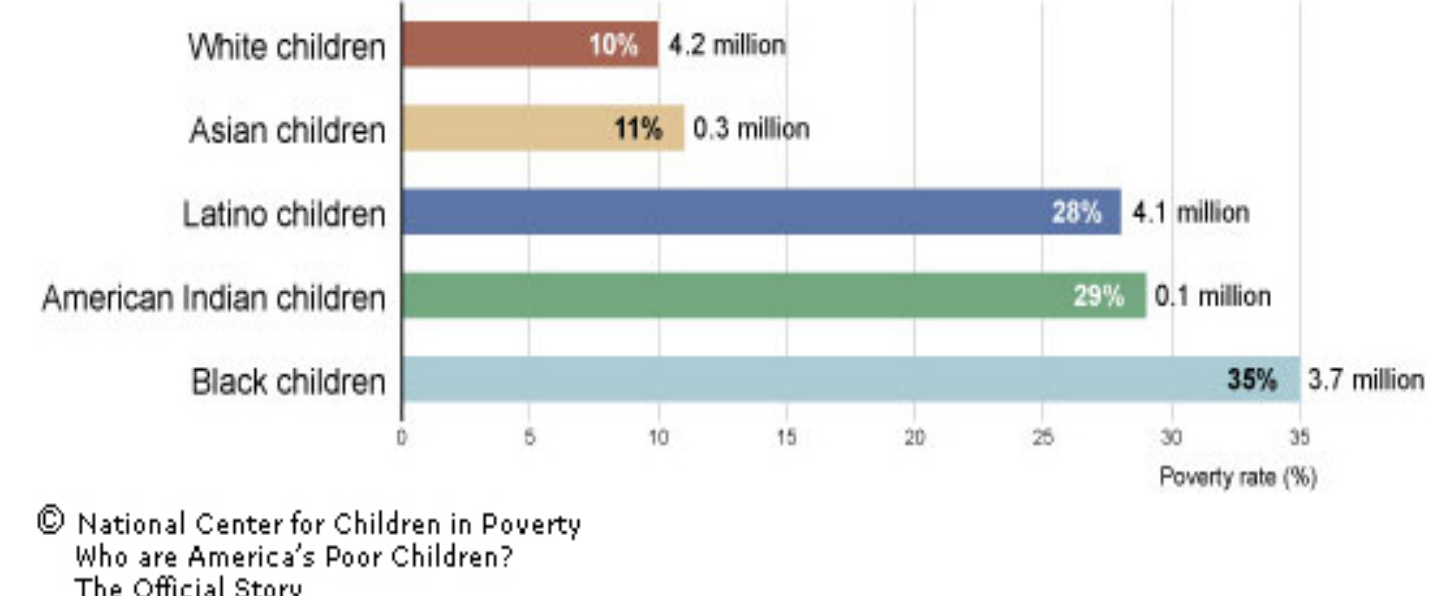

Generational and chronic poverty also affects black males at an alarming men and boys live in poverty, with 37 percent of black boys under the age of 18 and 42 percent of black boys under the age of five living in need.

[Figure 5]

These economic realities are closely ied to discriminatory policies that place many black males on a slippery slope. For them, it is a downward spialing slide through law enforcement and judicial system practices and policies long rigged to produce their isproportionately high ra males at the end of their time served is a lifetime of severely restricted access to good jobs and support services. Racial profiling and the high rate of rate. Twenty-six percent of all black convictions. Often awaiting black incarceration among black males are blocking the path to opportunity for many men and boys. Black men are disproportionately represented in our tion's prison populations. Of the 2 million people currently incarcerated, 1 million are black. One in three black men can expect to go to prison in their lifetime. For men ages 18-19, the imprisonment rate of blacks is nine times higher than that of whites for men ages 20-24, the rate is seven es higher for blacks.

oung black males account for 26 percent of juvenile arrests, 44 perce of youth who are detained, 46 percent of those who are judicially waive to criminal court, and 58 percent of young offenders who are admitted to of black men have been locked out of the democratic process and lost their that prohibit convicted felons from voting.

The vast inequities that exist in education, economics and our criminal justice system continue to cause grievous harm to the very fabric of the our communities and our nation.

The fight to reclaim the promise of racial equity is one that must be waged by all of us-labor unions, community believe the andividuals - who wide the pathways to equity and opportunity. African-American family, as well as 


\section{Racial Equity Task Force Recommendations}

The following

recommendations

provide a starting

point for our

union's work

around racial

equity. They offer

a context for the

development of

national and state

legislation, AFT

policy and local

school board policy

that support our

aspirations for

racial equity.
Our aspiration for equity in education:

Guarantee world-class public schools in every neighborhoo so that young black male students have equal opportunity to achieve. Ensure our schools provide safe, welcoming and caring spaces for students and educators to guarantee effective teaching and learning. Reduce suspension rates and brea
the school-to-prison pipeline for young black males.

Actions:

Increase access to mentoring and counseling services for young bla males-both inside and outside school, starting in preschool. - Incorporate inclusive restorative justice into discipline policies. -Zero-tolerance policies were an attempt to make schools safe and orderly, but that approach has not worked. We need policies that will help ensure that our schools trily do provide safe and welcom

Push for professional developmen that helps educators become aware of their own personal biases, as we as training for school safety and security personnel.

- Build partnerships with parents and community to provide wraparoun services for young black males.
Radically increase the percentage of college- and career-ready young black males.

Actions:

- Push for increased access to

high-quality universal pre-

high-qualty universal pre-

Advocate for and help educate

parents around special education

identification issues.

- Provide more supports and

information for parents of young

black males around college entry requirements.

Build support services to help reduce the attrition rates of young black males in colleges.

\section{Develop culturally competent}

educators, students and education

systems.

(Definition of cultural competence: The capacity to understand, respect a d respond effectively to differect students' cultures, com igstites power dyamics across social goups, power dynamics across social groups, integrating personal awareness with systematic change orientation.

Actions

dvocate for better education around cultural competency at all levels of the education system. - Ensure all curricula are culturally inclusive, accurate and relevant. - Develop and implement programs to identify, recruit, develop and retain black male educators.

Engage with the community to provide resources that meet the speciic needs of young black males.
Our aspiration for equity

in economics:

Ensure black men have equal access to and opportunity for obs with good wages, security and dignity.

Increase access to educational opportunity-particularly early childhood education, career and technical education, and higher education.

Actions:

Increase investments in community colleges.

Develop model legislation aimed at improving access to high-quality education at every level (for example, through community schools).

- Advocate for robust career and

technical education opportunities through public high schools, community colleges, apprenticeship program internships and mentoring

\section{Increase access to and preparation} or higher-paying jobs.

\section{Actions:}

- Lead the fight for livable wages.

- Support existing efforts by advocates for ex-offenders to persuade employers to remove from their

hiring applications the check box thing ask if applica check b

criminal record.

- Encourage investment in infrastructure improvennent projects as a way to increase good-paying jobs.

\section{Address inequities in taxation an}

revenue-generating policies.

- Advocate for changes in tax policies so that the wealthy

Redirect revenue spent on prisons

to provide more resources for local, state and federal budgets.
Our aspiration for equity

in criminal justice:

Ensure fair and equal treatment of black men and boys, and end institutionalized racism in the

criminal justice system.

Advocate for fair policing through

reater transparency and account-

ability, which will lead to safer communities.

Support community policing as a

way to rebuild relationships betwee

law enforcement and the communities they serve.

- End programs that put military weapons in the hands of local police and encourage police forces to discontinue using this equipment.

- Advocate for cultural competency training for police to encourage a better understanding between police better und police to ecticeen police ties where they work.

Work to combat factors that lead the mass incarceration of young black males.

Work with organizations to educate the public around the harmful toxic and traumatic effects of incarceration on families, communities an the nation.

- Advocate for alternative sentencing and options to incarceration, like treatment and support-especially

End mandatory minimum prison sentences for nonviolent drug crimes.

Push for decriminalization of nonviolent drug offenses.

- Eliminate private and for-profit prisons.
- Encourage policies aimed at reforming monetary bail requirements tha lead to the unjust imprisonment of underprivileged offenders who can't afford payment.

- Remove criminal records (particularly for nonviolent drug offenses) as disqualifying factors for educational funding and employment opportunities.

Push for full funding for social services-like mental health and addiction treatment-as a way to sten the mass incaction of young black 


\section{Reclaiming the Promise of Racial Equity}

The AFT's work in the area of racial equity represents a momentous renewal of our commitment to the values that have inspired and sustained our union for nearly 100 yea It builds on the fights we have wage for fairness in public education, Elementary and Secondary Education And while this work is not new to ou Act of 1965. This important education not finished.

legislation, which was a centerpiece

\section{A Commitment to Fairness}

Over the years, the AFT has led the fight for fairness in education for students of color by working to:

Break the school-to-prison pipeline by addressing disparities in how school discipline codes are enforced. Through a grant program, we are working with local affiliates to make changes at the school and
codes of conduct and to improve school climates. Incorporate restorative justice practices into school discipline codes through
our efforts with a working group that includes educators, administrators and community advocates, who have completed a restorative practices guide

for educators.

Combat the culture of low expectations by fighting for academic standards that define what all students should know and be able to do. We also have fought for curricula and pathways to engage the whole child through art, music, and socia for students who are struggling as an alternative to retection and social promotion practices.

Keep neighborhood schools intact and make them the focal point and heart of their communities, particularly in high-poverty neighborhoods. Through partnerships with labor, management and the community, schools can become places that provide valuable services that help lift students and their families. Ensure robust teaching environments by fighting the culture where testing replaces quality instruction.

Maintain public funding for public schools, especially those that serve the students in greatest need, by fighting for equitable funding.

Support struggling students by advocating for smaller class sizes and quality early childhood education programs with properly trained staff. We've push for Kindergarten-Plus programs to provide additional instruction time for Ensure there is a qualified teacher in every classroom by supporting the Nation Board for Professional Teaching Standards and contract language and legislation

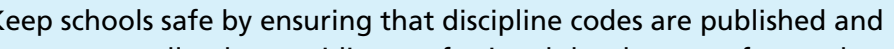

management.
As we forge a path for the future our fight for racial equity offers a unique opportunity to engage with our members and community partners in new ways. The starting point, however, is reflection and internal examination-as a union at every level and as individuals. We must ensure that our union-at the national, state and local levels-is working to create opportunities for black males in leadership and employment in workplaces throughout

Our fight for racial justice remains the unfinished business of our union and the country. While our commin the country criminent to end racial dislack lack of aftordable housing and an appalling lack of opportunity for African-American men is informed by our past, we feel, in the immorta words of Martin Luther King Jr., "th fierce urgency of now." We have a moral obligation to act and to begin having the tough conversations inside our union about how we will work together to confront the racia and economic barriers that are preventing millions of our citizens from enjoying a full and free life. In the end, we must be the change-and we must do everything we can to accelerate it.

The success of our efforts depends on our willingness to take the time to educate and engage our members-at the national, state and con individur bariers to social and including including our own personal biases, privis and engagement of every segment in our

Three Expressions of Racism Figure 6

union and members of every race and thnicity, particularly white members. Nearly 60 years ago, a number of progressive white and black AFT leaders stood together and took bold action by expelling local affiliates that refused to integrate after the landmark Brown $v$. Board of Education decision. Today, we implore everyone in our union-white and people of color-to stand with us in the fight forward.

With this report, the members of the Racial Equity Task Force are issuing an urgent call to action. We believe our union can and must take a lead in fulfilling the shared moral obligation fight for a sust cociety As Gondhion to Ght for a just society. As Gandhi said more than a century ago, we must be the change we wish to see in the world. The task force unges our natonal union and affiliates to hold tough, honest

racial equity conversations and workshops to expand awareness, deepen understanding and build a widely shared commitment to act. Conferences and conventions, regional meetings and other gatherings of our union provide racial equity educational opportunities that can uncover ways to operationaliz the policy recommendations outlined in this report and combat racism at the cultural, institutional and individual levels that it is expressed.

[Figure 6]
Individual Level

1. Personal

Structural Level

2. Institutional

$\left\{\begin{array}{l|l}\text { White } & \text { People of Color } \\ \hline \text { Validate } & \text { Invalidate } \\ \text { Resource } & \text { Exploit } \\ \text { Include } & \text { Exclude } \\ \text { Serve } & \text { Underserve }\end{array}\right.$

3. Cultural (Beliefs, Norms, Values)

"If the culture does not change, the progress toward equity will be easy to undo. 


\section{Our Fight Forward}

"The term 'microaggression' was used by Columbia professor Derald Sue to refer to 'brief and commonplace daily verbal, behavioral, or environmental indignities, whether intentional or unintentional, that communicate hostile, derogatory, or negative racial slights and insults

toward people of color.' Sue borrowed the term from psychiatrist

Dr. Chester Pierce, who coined the term in the '70s."

- HEBEN NIGATU, BuzzFeed

Therefore, as we move closer to our 100th anniversary as a union and our convention in July 2016, the time has come for the AFT to take on this issue in a bold, decisive way that results in real change in our nation, our communities and our schools. We ask the AFT executive council to approve this report and the recommendations as a first step in our fight forward. We believe the following recommendations provide a framework for the development of policyin national and state legislation, at the local school board level and inside the AFT:

- Fund programs that provide alternatives to out-ofschool suspensions that offer meaningful educational opportunities for black male students.

- Change school discipline policies to include restorative justice and fairer enforcement.

- Develop and implement programs to intentionally help identify, recruit, develop and retain black male educators and staff.

- Provide professional development and cultural competency training that helps teachers and other schoo staff understand their own personal biases.

- Create review processes in schools to ensure that black male students are treated fairly.
Develop funding, mentoring and counseling to create greater opportunity for black males to attend college. - Establish partnerships with trade unions to develop apprenticeship programs that provide job training and placement in trade careers that open the door to economic opportunity and independence for black men.

- Continue and expand our work with the Conferences of Chief Justices to help establish engagement strategies to bridge the gap between minority and low-income communities and court leadership through collaborative efforts that will increase public trust and confidence in the states' courts. 
Appendix I

AFT Racial Equity Task Force Members

Lorretta Johnson, AFT Secretary-Treasurer
TASK FoRCE CHAR

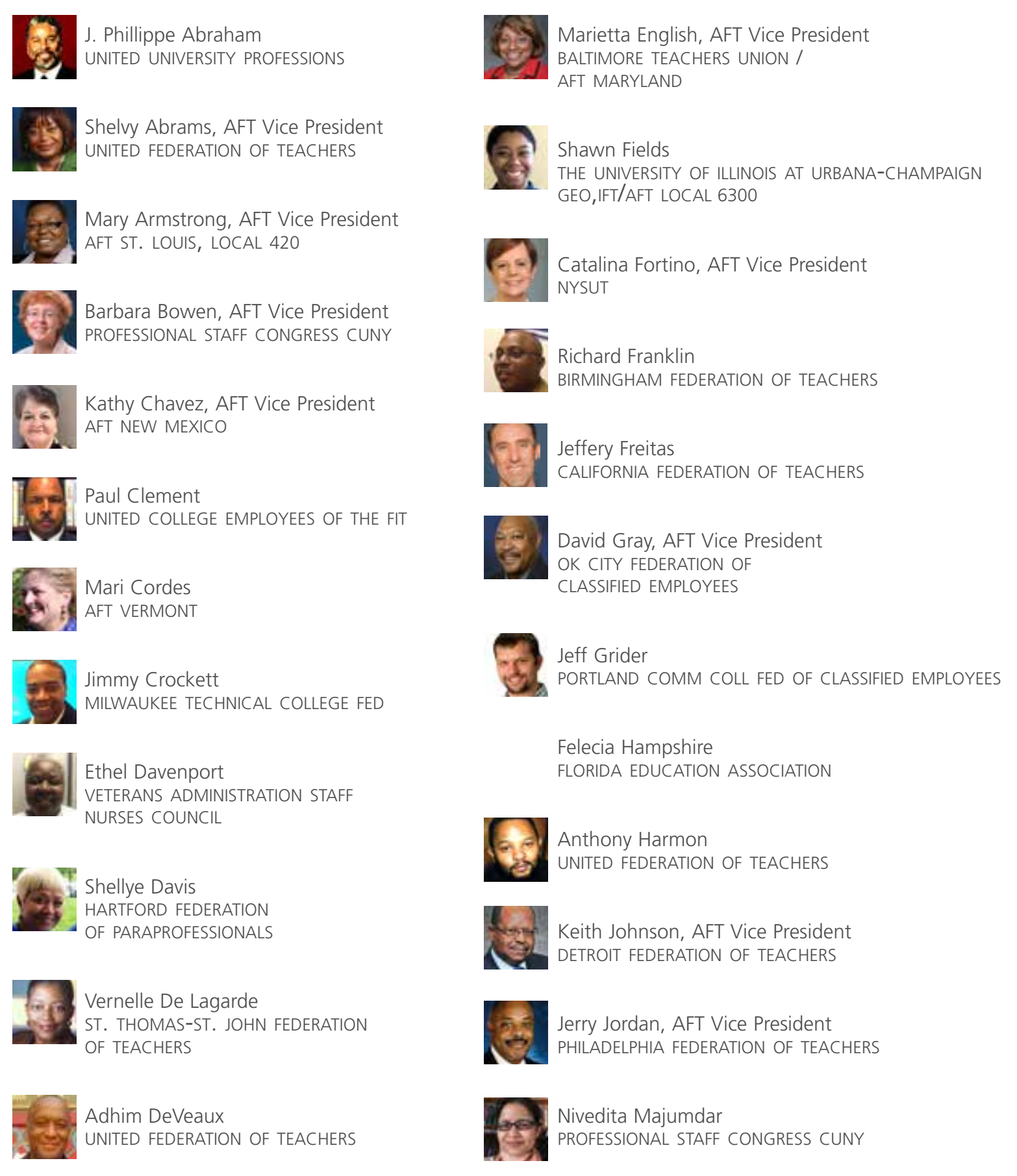

(5) Wende Marshall

69. Ruby Newbold, AAT Vice President

(2). Lisa Ochs

63 Candice Owley, AFT Vice President

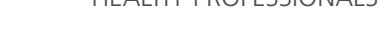

Q. Debra Perry

29. Darlene Post

21. Shelley Potter

(a) SAN PONO ALAANCE OF TEACHERS

C. Stephen Rooney, AFT Vice President
NATIONAL FEDERATION OF NURSES

Antoinette Ryan-Johnson
CITY UNION OF BALTMORE

(bod) Connie Smith WISCONSIN FEDERATION OF NURSES AND EALTH PROFESSIONALS

Irene Soto
KANSAS ORG OF STATE EMPLOYEES

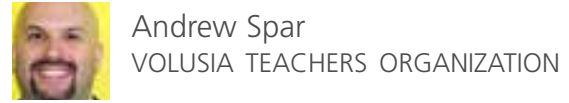


Appendix II

Recommended Readings

Educational Justice

"Creating Healthy Living and Learning Districs. http://bit.ly/HealthyDistricts

"Black Lives Matter: The Schott 50 State Report

on Public Education and Black Males,

http://bit.ly/Solutions_Initiative

"Invisible Men." Black Lives Matter, Shott Report

http://bit.ly/lnvis

State by State Graduation Rates

http://bit.ly/Graduation_Data

"After the Uprising: Uplifting Baltimore's Yo

"Analysis Finds Higher Expulsion Rates for

"Analysis Finds Higher Expulsion Rates for
Students." New York Times. Aug. 24, 2015.

Motoko Rich.

Black Male Donor Collaborative

http://bit.Iy/Donor_Collaborative

"Community Centered School Reform." Warren Simmons, Annenberg Institute.

http://bit.ly/Smart_EdSys

Early Childhood Education Assembly (ECEA)

Statement about the Role of Early Chilhood

Education and Racism

\section{http://bit.ly/ECE_Racism}

"Helping Children Thrive: Child Health Survey

Report." American Federation of Teachers.

UCLA Civil Rights Project Mission Statement

http://bit.ly/CivilRights_Mission

Partners for Each and Every Child

www.foreachandeverychild org

wering

"reaching about Ferguson. Race and Racism

"Why Schools Need More Teachers of Color-

\section{http://bit.ly/TeachersofColor}

"Dear White Teacher." Chrysanthius Lathan. Rethinkhttp://bit.ly/White_Teacher

"Editorial: Restorative Justice, What It Is and What

Schools Volume 29, Issue 1

Fall 2014.

"Are We Closing the School Discipline Gap?" The Civil Rights Project, UCLA, rebruary 23,

"Black Lives Matter: Building the school-to-justice piseline." Rethinking Schools, Volume 29, Issue 3 , Spring 2015.

http://bit.ly/Justice_Pipeline

"Whose Problem is Poverty?" by Richard Rothstein, ASCD, April 2008.

http://bit.ly/Poverty_Learning

Economic Justice

"Architecture of Segregation: Civil Unrest, the Concentration of Poverty and Public Policy." Century Foundation report

作: f-segregation

"Campaign for Black Male Achievement: Black "Male Achievement Dashboard"

http://bit.ly/BMA_Dashboard

"How Some Baltimore Neighborhoods Reflect Segregation's Legacy." NPR interview with Richard Rothstein from Economic Policy Institute 6, 2015

:

"The Link Between Police Tactics and Economic Conditions Cannot Be Ignored." The Guardian, 8, 2015 .

\section{//bit.ly/Police_Tactics}

"How Some Baltimore Neighborhoods Reflect Segregation's Legacy." Transcript of NPR

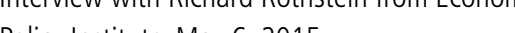
Policy Institute, May 6, 2015.

\section{hitp:/Bit.ly/Segregration_Legacy}

"From Ferguson to Baltimore: The Fruits of Government-Sponsored Segregation." Richard Rothstein. Working Economics Blog of the Eco-

http://bit.ly/Ferguson2Baltimor

Criminal Justice

Campaign Zero - Black Lives Matter activists

emanding specific policy proposals

Costion or Graduate Employee Unions (CGEU)

Resolution on Black Lives Matter
"Editorial: Restorative Justice: What It Is and Wha

Justorative_Justice

minantly black Southern churches "Lurn within a week... June 29 - Linsey Bever tep:/hit.ly/Churches_Arson

"low Newark Held Its Police Accountable" (video) _to://bit.ly/Criminal_Justice

"The Bail Trap," New York Times Magazine

//bit.ly/Bail_Trap

The New Jim Crow. Michelle Alexander

http://newjimcrow.com/

"What's Wrong with America's Juvenile Prisons." Francis Guzman

http://bit.ly/Juvenile Prisons

"Justice System is Failing Young Black Men."

http://cnn.it/1hhG3B4 


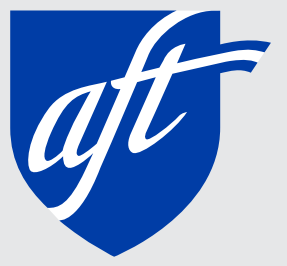

A Union of Professionals

American Federation of Teachers, AFL-CIO

555 New Jersey Ave. N.W.

Washington, DC 20001

202-879-4400

(4) aft.org Aftunion (y) @AFTunion (i) AFTunion 